\title{
Wine Tourism After The Direct Shipment Revolution: Implications And A Proposed Methodological Framework
}

\author{
Martin A. Goldberg, (Email: Mgoldberg@Newhaven.Edu),University Of New Haven
} James Murdy, (Email: Jmurdy@Newhaven.Edu), University Of New Haven

\begin{abstract}
The United States Supreme Court recently considered challenges to two state laws regarding direct shipment of wine and spirits from out-of-state. Michigan law banned these direct shipments completely, requiring sales from out-of-state to be made through a Michigan wholesaler, even though it permitted direct shipments from within the state. New York law similarly banned direct shipments, although it created a narrow exception for out-of-state wine producers who maintained a place of business within New York. In Granholm v. Heald ${ }^{l}$, the United States Supreme Court considered the constitutionality of these laws in light of the constitutional prohibition against state laws that unreasonably burden interstate commerce. The Court held that these laws did in fact impermissibly discriminate against interstate commerce, and were unconstitutional. It held that a state may permit direct shipments or prohibit them, but it could not create a discriminatory system where in-state direct shipment were permitted but out-of-state shipments were prohibited or burdened with additional costs. This decision left it to the individual state governments to fashion whatever direct shipment laws they wished, as long as the laws did not treat shipments from out of state differently from shipments within the state. As the individual states respond to this mandate, we can see how these new laws will impact wine tourism, actual and Internet travel for the purpose of experiencing and purchasing regional wines.
\end{abstract}

\section{INTRODUCTION}

ine tourism is an increasingly popular form of special interest tourism. Tourists engaging in this type of leisure travel visit wineries to sample their products, learn about wine production, enjoy the foods found in the region, and sightsee in some very dramatic and beautiful landscapes. In addition, wine and food festivals also attract tourists to wine producing areas ${ }^{2}$. Both the wine and tourism industries benefit from this form of special interest tourism. Tour operators, hoteliers, and other components now have expanded markets to market, and vintners gain increased exposure to new customers interested in their products. Despite tourists' interest in purchasing wine directly from the winery for shipment home, as well as subsequent purchases made from home, twenty-eight states had prohibited this type of commerce until recently ${ }^{3}$.

Some form of wine tourism has existed since the mid-1800s ${ }^{4}$. As early as the period of the Grand Tour, visiting wineries as a component of leisure or business travel has been documented. More recently, wine tourism has become a popular form of special interest tourism, supported by wine trails, festivals, and tour operators developing and delivering customized wine tours. Geographically, wine tourism exists throughout the world, with historic leaders

\footnotetext{
${ }^{1}$ Granholm v. Heald, 125 S. Ct. 1885; 161 L. Ed. 2d 796 (2005)

${ }^{2}$ Yuan, J., et al., An Analysis of Wine Festival Attendees' Motivations: A Synergy of Wine, Travel, and Special Events?, Journal of Vacation Marketing, Jan 2005, pp. 41-58.

${ }^{3}$ McFadden, D.L., Interstate Wine Shipments and E-Commerce, AEI-Brookings Joint Center for Regulatory Studies, March 2003, pp. 1-7.

${ }^{4}$ Hall, C.M., et al., Wine Tourism: Development, Management, and Markets, 2002, Butterworth-Heinemann.
} 
being the French and German wine producing regions. Wineries located throughout North America, including Napa and Yakima Valleys, New York state, and Ontario, Africa, Australia and New Zealand have all profited from increased visitation to their wineries.

The growth of the wine tourism industry benefits many businesses in these areas. Porter identified a number of businesses that are directly or indirectly influence by visiting wineries, wine grape growers, and other wine related attractions ${ }^{5}$ These industry clusters include grape stock, cultivation materials and equipment, governmental agencies at a variety of levels, vineyards, wineries/processing facilities, bottle and barrel makers, marketing organizations, and trade publications, to name a few. Given the wide range of products and services required to support wine tourism, the cluster has both domestic and global implications for suppliers. This economic dynamism contributed to the rapid growth of the wine tourism sector. In this context, the economic impact of wine production, including wine tourism, is staggering. In Napa Valley, CA, the total economic impact is estimated at $\$ 9.5$ billion annually ${ }^{6}$. Similar impacts are found in other wine producing regions of the United States. In fact, more that 40 states now actively engage in viticulture, and there are now over 3,000 wineries located throughout the 50 states. The industry generates 556,000 jobs and over $\$ 3.3$ billion in taxes ${ }^{7}$.

Unfortunately, wine tourism has always been burdened by the taint of alcohol as a vice, and a legal system that reflected that taint. It is sometimes hard to imagine that in just the last century the U.S. Constitution was amended to prohibit alcohol. The repeal of prohibition in the 21 st Amendment was accompanied by a great deal of trepidation as to the dangers of alcohol. Justice Stevens, dissenting in Granholm v. Heald, noted:

In the years following the ratification of the Twenty-first Amendment, States adopted manifold laws regulating commerce in alcohol, and many of these laws were discriminatory. So-called "dry states" entirely prohibited such commerce; others prohibited the sale of alcohol on Sundays; others permitted the sale of beer and wine but not hard liquor; most created either state monopolies or distribution systems that gave discriminatory preferences to local retailers and distributors. The notion that discriminatory state laws violated the unwritten prohibition against balkanizing the American economy--while persuasive in contemporary times when alcohol is viewed as an ordinary article of commerce--would have seemed strange indeed to the millions of Americans who condemned the use of the "demon rum" in the 1920's and 1930's. Indeed, they expressly authorized the "balkanization" that today's decision condemns. Today's decision may represent sound economic policy and may be consistent with the policy choices of the contemporaries of Adam Smith who drafted our original Constitution; it is not, however, consistent with the policy choices made by those who amended our Constitution in 1919 and $1933 .^{8}$

Justice Stevens' dissent, while not garnering majority support of the Court, still fairly describes what has been the state of affairs of state liquor law after Prohibition repeal. That is, each state has had broad powers to enact laws regulating a product regarded as a vice, if not downright evil, and the result has been a patchwork of laws detailing who can sell alcohol, when alcohol can be sold, what kinds of alcohol can be sold, and what kind of chain of distribution there is between the producer of the alcohol and the ultimate consumer. States can control the brands of alcohol sold as well as the type of container alcohol is sold in, and can prohibit sales of food, cigarettes, or even types of entertainment in an establishment that sells alcohol. It is hard to imagine a state law saying that bread could not be sold in the same store as butter, but we have come to take it for granted that a state law can prohibit a store that sells distilled spirits from also selling beer (or milk, for that matter).

It is against the background of inconsistent and arbitrary state liquor laws that we see the Granholm case. The Granholm case stated unambiguously that even with the broad powers granted to the states under the 21 st Amendment, state laws still cannot be in violation of other provisions of the U. S. Constitution. In particular, states' powers are subject to the Commerce Clause of the Constitution, which gives the federal government the power to

\footnotetext{
${ }^{5}$ Porter, M. E., Location, Competition, and Economic Development: Local Clusters in a Global Economy, Economic Development Quarterly, Feb 2000, pp. 15-34.

${ }^{6}$ Napa Valley Vintners Association, retrieved from http://www.napavintners.com/news/press_kit_facts.asp

${ }^{7}$ American Wine Society, retrieved from http://www.americanwinesociety.com/web/wine_facts_figures_htm

${ }^{8}$ Id., at page 1909 , footnotes omitted.
} 
regulate interstate commerce. The implicit converse of the Commerce Clause, called the "Dormant Commerce Clause," holds that states may not unreasonably burden interstate commerce, and a state law that discriminates against out-of-state business does just that. Accordingly, the Court held, state laws that permitted direct shipment of wine and other alcoholic beverages, where shipments from out-of-state were prohibited or made more expensive, would be unconstitutional under the Commerce Clause.

It may be, as Justice Stevens argued, that the Granholm case reflects current sensibilities more than it does a fair reading of the 21st Amendment. Be that as it may, from a business standpoint, it does reflect a modern notion that alcoholic beverages are an ordinary staple of commerce, and that there are limits on how much power states have over such a product.

The holding of this case was a clear victory for all producers of alcoholic beverages in general. But there is a lingering question of how much impact this ruling will have on smaller wineries who were more inclined to sell to directly to tourists who had personally visited their premises. Will the effect of this new legal era be limited, just boosting Internet sales of California and other prestigious wines, or will there be a measurable benefit to wine tourism throughout the country, even in those states without a special reputation for wines?

The purpose of this paper is to propose a framework for assessing the impacts of the Granholm case on wine tourism. We will develop a multidimensional framework that will include impacts of the decision on the wine producers, on wine tourists, and as it relates to categorizing the responses of individual state legislatures. It is the purpose of this paper to examine how this change affects wine tourism, particularly for these smaller wineries.

\section{REVIEW OF LITERATURE}

The academic literature concerning wine tourism has grown with the levels of visitation to wineries. Some of this literature addresses the economic issues associated with this form of special interest tourism. Unlike most areas of commerce, economic impacts analyses are not easily found ${ }^{9}$. This dearth of literature may be attributed to the focus on the development of wine tourism. In this area, a number of authors focus on specific regions that seek to benefit from wine tourism. For example, Beames ${ }^{10}$, Martin and Williams ${ }^{11}$, and Hall and Mitchell ${ }^{12}$ all stated that because of the importance of wine tourism to Australia, British Columbia, and the Mediterranean (respectively), economic and development policy pertaining to wine tourism is of paramount priority to governments and vintners. The work of Macionis ${ }^{13}$ best exemplifies the research addressing governmental and supplier involvement in creating and sustaining the wine tourism market.

Although studies on wine tourism policy and economics are inchoate, the research concerning leisure travelers visiting wine-producing regions is well-developed. From this perspective, studies on wine festival attendance ${ }^{14}$ and wine tourists ${ }^{15}$ both address the motivations for engaging in wine tourism. Among the reasons cited

\footnotetext{
${ }^{9}$ VanAusdle, S. L., Changing Times for Rural Prosperity Through Wine, Food, and Art, Community College Journal, Jun/Jul 2005, pp. 10-14.;

${ }^{10}$ Beames, G., The Rock, the Reef and the Grape: The Challenges of Developing Wine Tourism in Regional Australia, Journal of Vacation Marketing, June 2003, pp. 205-212.;

${ }^{11}$ Martin, E., \& Williams, P. Directions in British Columbia Wine Tourism Policy, International Journal of Contemporary Hospitality Management, 15, 6, pp. 317-323.

${ }^{12}$ Hall, C. M., and Mitchell, R., Wine Tourism in the Mediterranean: A Tool for Restructuring and Development, Thunderbird International Business Review, July/Aug 2000, pp. 445-465.

${ }^{13}$ Macionis, N., Wine Tourism: Making It work for the Long Term, The Australian and New Zealand Wine Industry Journal, 13, 2, 1998, pp. 127-131; Macionis, N., and Cambourne, B., Wine Tourism: Just What Is It All About?, The Australian and New Zealand Wine Industry Journal, 13, 1, 1998, pp. 41-47.

${ }^{14}$ Yuan, J., et al., op. cit.

${ }^{15}$ Mitchell, R., Hall, C. M., and McIntosh, A., Wine Tourism and Consumer Behavior, in Hall, C.M., et al. (eds.), Wine Tourism: Development, Management, and Markets, 2002, Butterworth-Heinemann; Hall, C. M., and Mitchell, R., Wine and Food Tourism, in Douglas, N., Douglas, N., and Derrett, R. (eds.) Special Interest Tourism, 2001,
} 
for participating in wine tourism, education, entertainment, relaxation, socializing, eating, the scenery, and purchasing wine are commonly are common. As with the work on policy and economics, wine tourist motivation also appears to be focused, at least partially, on the opportunity to increase sales of wine. In general, the "cellar door" sales and service are often cited as primary motivators for both the producers and consumers of wine tourism products ${ }^{16}$. Given the significance of wine sales to the wine tourism industry and the recent decision in Granholm v. Heald, a methodology for assessing the potential changes to the wine tourism industry should be created and tested. Before discussing a suggested methodology which may include the effects of virtual wine tourism, a grounding in virtual tourism is necessary.

The rise of electronic commerce greatly affected the tourism industry. The development of new product distribution channels, on-line communities, and virtual destinations revolutionized how tourists consume destinations. Some locations restructured their electronic marketing through the creative linking of product and service websites through virtual cooperatives ${ }^{17}$. In this context, virtual tourism refers to the creation of a website that facilitates "visits" to hotels, restaurants, attractions, and other amenities found at the destination. The cooperative offers tourists an opportunity to see aspects of the destination from the security of home region, while minimizing suppliers' costs and risks in what may be a very competitive and volatile marketplace. These challenges may be partially addressed through the development of low cost, high impact marketing strategies, such as cooperative websites or the strategic placement of links to supporting businesses. This approach has been met with varying levels of success, such as the case of the King Hotel in Egypt ${ }^{18}$. Faced with a limited marketing budget and declining revenues, management developed a web presence that integrated information about the property's services and links to attractions and nightlife along with tips on the culture and travel to Egypt.

While ecommerce plays a substantial role in the creation of virtual tourism, online communities, often sustained by experienced travelers and the blogs, substantially influence the marketing efforts described above. Wang et al. ${ }^{19}$ developed a model of the virtual tourism community in terms of place, symbol, and virtual. In further describing this model, the authors identify the psychological, social and functional needs of virtual tourist and the implications of this model on tourism marketing. By creating new opportunities for branding, relationship building, product grouping, savings, revenue generation, and virtual community creation, tourism businesses now possess unprecedented opportunities to affect and be affected by tourists. These prospects may also influence subsequent visitation to a destination. Specifically, if tourists visit a region and learn that ecommerce facilitates the purchase of products and souvenirs from the destination, repeat visitation may decline. At the extreme, virtual tourists may decline leaving home, satisfied with the opportunity to travel, experience, and purchase products all online. The potential impact on wine tourism by virtual wine tourism must therefore be closely monitored, particularly in the current regulatory environment that reduced the barriers to direct shipment of wine. Logically, if the souvenirs of a wine tour (wines from the region) are readily available through the internet, and the tourists use these products as trophies or other material means of demonstrating their social, cultural, and financial acumen (akin to Veblin's conspicuous consumption), then the delivery of these souvenirs to consumers may result in declining wine tourism as buyers may seek to demonstrate their acuity for the romance of the grape by purchasing on line. All the while, the money formerly used to visit favorite wine producers is now used for other forms of tourism.

Wiley; Ravenscroft, N., and van Westering, J., Wine Tourism, Culture, and the Everyday: A Theoretical Note, Tourism and Hospitality Research, Sept 2001, pp. 149-162.

${ }^{16}$ Dodd, T. H., Influences on Cellar Door Sales and Determinants of Wine Tourism success: Results from Texas Wineries, in Hall, C.M., et al. (eds.), Wine Tourism: Development, Management, and Markets, 2002, ButterworthHeinemann; O'Neill, M., Palmer, A., and Charters, S., Wine Production as a Service Experience - The Effects of Service Quality on Wine Sales, The Journal of Services Marketing, 16, 4, 2002, pp. 342-362.

${ }^{17}$ Palmer, A., McCole, P., The Role of Electronic Commerce in Creating Virtual Tourism Destination Marketing Organizations, International Journal of Contemporary Hospitality Management, 12, 3, 2000, pp. 198.

${ }^{18}$ Kamel, S., and Jussein, M., King Hotel Goes Online: The Case of a Medium Enterprise in Using eCommerce, Journal of Electronic Commerce in Organizations, Oct-Dec 2004, pp. 101-115.

${ }^{19}$ Wang, Y., Yu, Q., and Fesenmaier, D., Defining the Virtual Tourist Community: Implications for Tourism Marketing, Tourism Management, 23, 2002, pp. 407-417. 


\section{THE U.S. SUPREME COURT DECISION AND CHANGES IN THE LEGAL LANDSCAPE}

Until recently, it was illegal for a resident of New York who visited an out-of-state winery to order more wine for direct shipment home. Many other states had similar laws. New York law allowed only two ways for an out-of-state winery to sell within the state of New York: either the supplier had to have an physical place of business in New York, or it had to sell through a wholesaler. Both of these alternatives were prohibitive for small wineries, and wine tourists were unable to have more wine shipped to them. So, when the wineries sued, these customers joined the suit, and the case went all the way to the U.S. Supreme Court.

In Granholm v. Heald ${ }^{20}$, The Supreme Court consolidated this case challenging the New York law with another that challenged a similar Michigan law. Michigan was even more restrictive than New York, allowing only resale through wholesalers. In both New York and Michigan, in-state wineries were not subject to these restrictions. This disparity in treatment for in-state producers provided their out-of-state competitors with the basis for their case. Representing the states were the states themselves, acting through their liquor control boards, and wine and beer wholesalers associations. These intermediaries had a vested interest in controlling imports of wine and opposing the direct shipment of wine to in-state customers

The question before the U. S. Supreme Court was the constitutionality of state laws permitting in-state wineries to ship directly to customers, but prohibiting or restricting the ability of out-of-state wineries to make direct shipments. The ensuing legal debate reached epic levels. The states and the wholesalers argued that the Twenty-First Amendment, which repealed Prohibition, granted broad powers to the states to regulate importation and sales of alcoholic beverages. Under these powers, they argued, the states had the right to treat in-state and out-of-state producers differently. The wineries and their customers argued that the state laws restricting direct interstate shipments were a burden on interstate commerce, which meant that only the U.S. Congress, and not the individual states, had the authority to enact such laws.

Ultimately, the U.S. Supreme Court sided with the small wineries and their customers. In the Granholm case, the Court noted that "State laws that discriminate against interstate commerce face 'a virtually per se rule of invalidity.' Philadelphia v. New Jersey, 437 U.S. 617, 624, 57 L. Ed. 2d 475, 98 S. Ct. 2531 (1978)." ${ }^{21}$ It held that the Twenty-First Amendment did not negate this rule for alcoholic beverages, and that the New York and Michigan laws were an unconstitutional burden on interstate commerce. The Court concluded, "If a State chooses to allow direct shipment of wine, it must do so on evenhanded terms." ${ }^{, 2}$ So, the states were left with a directive to fashion laws that meets this directive.

Many states already had rules that satisfied Granholm's Constitutional mandate. For instance, in the state of Utah, all direct shipments are banned, whether from within or outside of the state. ${ }^{23}$ Such a law creates no problem under the Supreme Court's recent decision, as it does not give favored treatment to in-state shipments. It may be that states that have a discriminatory ban will replace it with a non-discriminatory ban rather than repeal the ban completely.

The U. S. Supreme Court's decision seems to suggest that states will respond with either the proverbial thumbs up or thumbs down, in terms of banning or permitting direct shipments. Such a result would be a boon to wineries, which could then simply maintain a list of states that they could ship directly into, and those where they could not. Unfortunately, state law responses are not that simple. The states that do permit direct shipment generally accompany that permission with a host of requirements, so that any winery wishing to ship into that state needs first to know those requirements.

\footnotetext{
${ }^{20}$ Granholm v. Heald, 125 S. Ct. 1885; 161 L. Ed. 2 d 796 (2005)

${ }^{21}$ Id., at page 27

${ }^{22}$ Id., at page 57

${ }^{23}$ Utah Code Ann. § 32A-12-504
} 
For any given state law that permits direct shipments, the producer needs to know: Are all direct shipments permitted? Is there a license and a licensing fee? Are there special taxes? Is there a maximum amount that may be shipped into the state per producer? Is there a maximum amount that may be shipped into the state per consumer?

Perhaps this may indirectly be a burden on interstate commerce. After all, it may be relatively easy for a winery to ascertain the laws in its home state, but burdensome to keep track of the laws in the 49 other states. The Wine Institute, an advocacy group that represents 840 California wineries, ${ }^{24}$ maintains online information about stateby-state direct shipping laws and regulations. ${ }^{25}$ By way of comparing some of the different records that a winery might have to keep as reported by the Wine Institute, Connecticut law states that the total wine that can be shipped, combining onsite and offsite sales, is five gallons per customer every 60 days. New York has a limit of two cases per month, also for onsite and offsite sales. Each of these states has only a per-customer limit, not a per-producer limit. By way of comparison, New Hampshire will only permit a total of 1,200 cases shipped directly from any winery. So, the winery wishing to do direct shipments needs to keep track, not only of the state laws, but also the volume of shipments to each customer and/or to all customers within a particular state, as dictated by the laws of the individual states.

To make matters more complicated, states that permit direct shipping need to have the administrative cooperation of the shipping services, such as FedEx, UPS, and DHL. These shipping services need to ascertain that the recipient of a shipment is 21 years old (as well as other requirements that may be enacted by a particular state). Not every shipping service is capable of handling the legal needs of every state. ${ }^{26}$ This means, before a winery may ship to an individual, it not only needs to know and comply with the legal requirements, but it also needs to know which companies are in fact willing to accept and deliver the shipment. This may be just a temporary problem, as each state establishes its own direct shipment requirements, and yet it is another burden for the winery desirous of implementing a direct shipment system.

Although the Granholm case specifically addressed the New York and Michigan laws that discriminated against direct shipment of wine from out of state, the case may open the door to future constitutional challenges to restrictive state liquor laws. Notably, the Court said that the Twenty-First Amendment "does not supersede other provisions of the Constitution" 27 . While it is not likely that there will be a run on constitutional cases, this language does open the door to challenges of some of the more arbitrary state laws. After the Twenty-First Amendment it seemed to be assumed that state liquor laws were substantially beyond scrutiny under other provisions of the constitution. Now that this assumption has been successfully challenged, the case law can literally go anywhere.

\section{METHODOLOGICAL FRAMEWORK}

Because wine tourism has a minimum of two forms (virtual and on-site), a new method should be identified to capture the net effect of the changes to direct shipment law. One such method would include the development of tourist roles ${ }^{28}$, or stable and identifiable forms of tourist behavior, that may be used as market segments. Along these lines, Corigliano ${ }^{29}$ identified four such market segments. The Professional knows wines and the wine world, is conversant in wine jargon and trends, is a good judge of wines, and is very interested in discovering new wines and related products. The Impassioned Neophyte tends to use wine tourism as a social experience, often sustaining or improving friendships while visiting wineries. The Hanger-On knows the basics of wine and wine consumption, but is easily influenced by the opinions of others and enjoys wine tourism because of the social status (s)he may associate with it. Finally, the Drinker visits wineries as an alternative to bars and buys wines in bulk for the discounts

\footnotetext{
${ }^{24}$ http://www.wineinstitute.org

${ }^{25}$ At http://wi.shipcompliant.com/Home.aspx

${ }^{26}$ Id.

${ }^{27}$ Granholm v. Heald, supra, at page 46

${ }^{28}$ Pearce, P., A Systematic Comparison of Travel Related Roles, Human Relations, 38, 1985, pp. 1001-1011; Yiannakis, A., and Gibson, H., Roles Tourists Play, Annals of Tourism Research, 19, 287-303.

${ }^{29}$ Corigliano, M. A., Caratteristiche della Domanda Strategie di Offerta e Aspetti Territoriali e Ambientali, in Hall, C.M., et al. (eds.), Wine Tourism: Development, Management, and Markets, 2002, Butterworth-Heinemann.
} 
associated with this type of purchase.

These potential roles could be expanded to include two types of virtual wine tourists. True virtual wine tourists are those who never visited the winery or region, but uses virtual travel to familiarize themselves with the region. No purchase of the wine product is necessary to be included in this category. The repeat virtual tourists traveled to the region or winery, and subsequently buy their favorite wines directly through the internet. A last potential addition to the types of wine tourists includes those purchasing wines through mail-order providers. By learning about new wines via these catalogues, potential on-site and virtual wine tourists may be piqued to visit a new wine destination.

Although tourist role theory offers a methodologically rigorous means for typing tourists ${ }^{30}$, a frequent problem is the development of a sampling frame with sufficient numbers of each type of tourist. For example, Murdy $^{31}$ found low numbers of Nature Lovers, Explorers, and Eco-tourists among the 800 Connecticut residents surveyed for his study. Therefore, we propose a more encompassing approach to the identification and selection of participants. To begin, a targeted market should be used, such as Connecticut wineries. Because Connecticut is geographically small but has a number of wineries (some of which are award winning), it is an ideal place to examine the impacts of the direct shipment revolution. Next, partners in the wine industry will be asked to share their online customer database for inclusion in the study. These clients will be sent a survey, with reference to a virtual copy of the document, assessing the type of wine tourism in which they engage. Next, online wine purveyors representing Connecticut wineries will be asked to join the project through similar involvement. Finally, website hosts will be asked to post a direct link to the survey and encourage their virtual tourists to complete the survey.

By developing a survey assessing the role(s) chosen by the wine tourists and soliciting industry participation, a complete demand side assessment may be completed. The supply side impacts will require additional methodologies. Wineries looking to gauge wine tourism will need some method to account for the changes in their wine business. There are several different approaches that may be used.

\section{Contribution Margin Analysis}

The contribution margin is the difference between the gross sales and the variable costs. With a winery, the variable costs would include costs for the bottle, the cork, and the labor allocable to the additional wine produced. The fixed costs are unchanged by the addition of the new business activity, the direct shipments (at least, until there is a major change in the volume of the business). So, contribution margin analysis measures the incremental profitability of the additional sales without reducing the profit by costs that would have been incurred with or without those sales.

Fixed costs are not taken into account in determining the contribution margin. However, there are some reductions in profitability that would be taken into account. For instance, a winery that ship directly to its customers may be selling bottles that would otherwise have been purchased on site or at a package store. In addition, if the winery has an existing relationship with distributors, the distributors may invest less money in marketing the winery's wine if it feels that some of its business is being lost to direct shipments.

Contribution margin analysis has been criticized for allocating none of the fixed costs to an additional source of revenue, inflating the apparent profitability of a new venture. ${ }^{32}$

\footnotetext{
${ }^{30}$ Mo, C., Havitz, M., and Howard, D., Segmenting Travel Markets with the International Tourism Role (ITR) Scale, Journal of Travel Research, Summer 1994, pp. 24-31.

${ }_{31}$ Murdy, J., Predicting Tourist Role Preference Across the Life Course, 2001, unpublished doctoral dissertation.

${ }^{32}$ E.g., Robinson, et al., Contribution Margin Analysis: No Longer Relevant/Strategic Cost Management: The New Paradigm, Journal of Management Accounting Research, Fall 1990, pp. 1-32.
} 


\section{Standard Costing}

With standard costing, a prorated share of fixed costs is allocated to each product sold. Although the simplest costing technique, it is generally considered inaccurate, except where there is a single product at a fixed price. In the case of a winery, standard costing would tend to make the direct shipment activities appear to be more expensive, and less profitable, than they really are.

\section{Activity-Based Costing}

This analysis factors into the profitability of a sale a portion of fixed costs. In most cases, this would be considered a truer measure of profitability than contribution margin analysis, as the use by the winery of existing overhead (the winery premises and its employees) does have a cost in terms of taking this overhead away from other profitable uses to which they might have been put.

In the context of a typical small winery, however, this calculation is less clearcut. We can take a look at three fixed-cost items: the manager, the marketing person, and the Internet site. In all cases, additional time will need to be spent to accommodate the direct shipment business. There are three possible sources for that time:

First, the winery can hire independent contractors. In this case the winery can determine exactly how much cost is allocable to the direct shipment business. Second, the winery can use existing employees. In this case there is a cost, as the employees would be taking away time that might be spend on other profitable activities for the winery, and perhaps eventually require greater compensation. While there is an additional cost for this source of time, it is less clear how this can be determined, and a certain amount of estimation would need to be done. Third, the winery can use existing employees who are owners of the winery, or members of an owner's family. Since these individuals may put in additional time without taking time from other duties or requiring additional compensation, under this scenario it is less likely that the winery will be able to allocate a portion of the fixed cost to the new direct shipment activity. Thus, although contribution margin analysis has been criticized for inflating the apparent profitability of business activity, it may be the method that produces the most effective results in the context of a winery expanding into direct shipments.

Another consideration is that a small winery may have limited capacity to do complex cost and profit analyses. It may be that sales of units may be the best indicator of the success of the direct shipment operations. This too, is flawed, in that the profit margin is greater on direct sales than sales through wholesalers and retailers. However, as none of the accounting methods is without problems, this should be considered as a viable alternative.

There are two reasons why measuring the amount of wine shipped will be a better measure of the success of the direct shipment business than any of the accounting techniques. First, because many of the state laws contain maximum amounts that may be shipped, the winery will need to maintain records of this anyway, so there is no additional cost.

Perhaps more importantly, the profitability of direct shipment may not be uniform for all shipments. In the case of a state with complex laws and high licensing fees, it may be that direct shipments to such a state are less profitable than such shipments to a state with simpler laws and lower licensing fees. It may even be that a winery will eventually determine that direct shipments into certain states cannot be justified economically, particularly if there is a low volume of shipments to customers in such states.

In order to determine the impact of new direct shipment laws on wineries, quantitative data will need to be acquired. The information needed would include: How many bottles and cases of wine are shipped to consumers out of state? What are the gross receipts and variable costs associated with such sales? How many of these sales were made onsite? How many of these sales were made from an offsite location by someone who had previously visited the winery? How many of these sales were made from an offsite location by someone who had never visited the winery? How many visits to the winery resulted from an offsite purchase, and did any further purchases result from such visits? 


\section{INITIAL RESULTS AND CONCLUSIONS}

At the present time it appears that more states will be permitting direct shipments than prohibiting them. This will be a marketing opportunity for wineries, particular small, regional wineries, that lack the national profile of the larger wineries.

The exact legal landscape is still in a state of change. However, going forward, it will become clearer which states will be permitting direct shipments, and it will also be clearer what specific rules each of such states will have adopted. Wineries will be able to take advantage of these laws to promote their wines out of state, and to promote local wine tourism that includes visits to the wineries. The wineries will then determine the profitability of direct shipments as a new category of business, and then determine the profitability of direct shipments to individual states.

Early results from unstructured interviews with consumers indicates little or no change in buyer behaviors. Those in the industry stated that they perceived no direct impact of the Granholm decision on their business, nor had their colleagues with whom they had spoken recently. Others commented on the blatant disregard for direct shipment laws. In fact, one participant said that "we just ignored those laws". It should be noted, however, that these findings are very preliminary and represent a small $(\mathrm{n}=7)$ group of wine consumers.

Given the framework and literature described above, however, substantial changes to the wine tourism industry may be forthcoming. Virtual tourism of various forms may significantly influence the revenues of tasting rooms and cellar door sales as well as supporting product lines, such as food and paraphernalia, and therefore should be examined for the impacts of the direct shipment revolution.

\section{NOTES}




\section{NOTES}

